\title{
Vascular Hemostasis in Heifers on Rearing
}

\author{
Medvedev Ilya Nikolayevich (Corresponding author), \\ Kursk Institute of Social Education (branch) of Russian State Social Education, \\ Kursk, Russia
}

Zavalishina Svetlana Yur'evna

All-Russian Research Institute of Physiology, Biochemistry and Nutrition of Animals,

Borovsk, Russia

Received: August 11, 2015 Accepted: August 27, 2015 Available online: September 19, 2015. doi:10.5296/jas.v4i1.8332

URL: http://dx.doi.org/10.5296/jas.v4i1.8332

\begin{abstract}
On investigation of 42 healthy black-and-white breed heifers on rearing the tendency for the decrease of acylhydroperoxides and thiobarbituric acid content in their blood was stated as a result of increase of plasma antioxidant protection activity in them. On the background of the low level of endotheliocytemia in healthy heifers on rearing there was revealed a considerable upward trend of the antiaggregational activity indices in the vascular wall with all tested inductors and their combinations.

For endotheliocytes of heifers on rearing a tendency for gradual increase of antithrombin III production, ensuring the necessary level of anticoagulant blood capacity is evident. In animals from 12 to 15 months of life this was accompanied with increase of plasminogen tissue activators secretion by the vascular wall.
\end{abstract}

Keywords: heifers; rearing; hemostasis; vascular wall; lipid peroxidation.

\section{Introduction}

Alongside with genetic potential (Amelina and Medvedev, 2008, 2009), vascular hemostasis, provided with hemostatically significant substances produced in the vascular wall (Zavalishina, 2012a; 2012b), is considered to be one of important elements for supporting the homeostasis optimum in productive animals.

These substances are subdivided into compounds with antiaggregational, anticoagulant and fibrinolytic activity, regulating liquid properties of blood and homeostasis functioning on the whole, considerably determining the level of oxygen and nutrient substances supply to organs and tissues (Medvedev and Zavalishina, 2014a; Zavalishina and Medvedev, 2012).

Having great physiological and biochemical significance, a vascular wall determines 
functional characteristics of an organism to a considerable state (Medvedev, Gromnatskij, Volobuev, Osipova and Storozhenko, 2006; Medvedev, 2007; Simonenko, Medvedev, Mezentseva and Tolmachev, 2007; Simonenko, Medvedev and Kumova, 2010).

There is no doubt, that on all stages of an organism growth and development vascular hemostasis has an important role in providing the adaptation process (Medvedev, Zavalishina and Krasnova, 2010; Medvedev and Zavalishina, 2015).

But, in spite of the significance of the vascular control in thrombocyte aggregation and hemocoagulation (Krasnova and Medvedev, 2013a; Krasnova and Medvedev, 2013b; Medvedev and Zavalishina, 2012), it is still not sufficiently investigated in heifers on rearing.

The capacity of the vascular wall to synthesize antiaggregants, antithrombin III (AT III) and plasminogen tissue activators, which is significant for the future younger animals' productivity, is still not elucidated.

The present investigation was planned and conducted due to the highlighted gaps in the system of biological knowledge.

\subsection{Purpose of the study}

The aim is to determine functional capacities of the vascular wall hemostatic activity in healthy heifers on rearing.

\section{Methods}

The investigation is conducted in the spring-summer period involving 42 healthy black-and-white breed heifers on rearing, kept at the cattle breeding farm "Grand", Kursk region, Russia, which were inspected 4 times: at the age of about 12 months, about 13 months, about 14 months and about 15 months.

The survey included the determination of plasma lipid peroxidation (PLP) activity according to the acylhydroperoxides (AHP) (Gavrilov and Mishkorudnaja, 1983) and thiobarbituric acid (TBA)-active products level using the "Agat-Med" set with the estimation of the antioxidant activity (AOA) of the liquid part of blood (Volchegorskij, Dolgushin, Kolesnikov and Cejlikman (2000).

Endotheliocytemia amount was recorded according to Zainulina M.S. method (Zainulina, 1999).

The state of the vascular wall antiaggregational ability was determined according to (Baluda, Sokolov and Baluda, 1987) on the basis of visual micromethod of thrombocyte aggregation (TA) recording (Medvedev, Zavalishina, Kutafina and Krasnova, 2015; Shitikova, 1999) with $\operatorname{ADF}\left(0,5 \times 10^{-4} \mathrm{M}\right.$.), collagen (dilution $1: 2$ of the basic suspension), thrombin $(0,125 \mathrm{u} . / \mathrm{ml})$, ristomycin $(0,8 \mathrm{mg} / \mathrm{ml})$ and adrenalin $\left(5,0 \times 10^{-6} \mathrm{M}\right)$, and also with their combinations: ADF + adrenalin, $\mathrm{ADF}+$ collagen, collagen + adrenalin, $\mathrm{ADF}+$ thrombin, $\mathrm{ADF}+$ collagen + adrenalin, $\mathrm{ADF}+$ thrombin + adrenalin and $\mathrm{ADF}+$ collagen + thrombin + adrenalin in concentrations similar to standardized amount of thrombocytes $\left(200 \times 10^{9}\right.$ thr. $)$ in the investigated plasma before and after temporary venous occlusion with determination of the vascular wall antiaggregational index (VWAAI) by dividing TA time at temporary 
phlebostasis by TA development time without it.

Anticoagulational control of the vascular wall in animals was found out in accordance with the value of the vascular wall anticoagulant activity index (VWACAI), which was counted by dividing AT III activity (Barkagan and Momot, 1999) after venous occlusion by its value before it (Baluda, Sokolov and Baluda, 1987). To find out the degree of the vascular wall influence on the fibrinolytic blood activity the method of euglobulin lysis (Barkagan and Momot, 1999) time determination before and after temporary venous occlusion, causing the plasminogen tissue activator (Baluda, Sokolov and Baluda, 1987) discharge from vascular wall into blood, was used with determination of the vascular wall fibrinolytic activity index (VWFAI) by dividing euglobulin lysis time before the occlusion by the lysis time after it.

To determine the accounted biochemical data and TA, blood samples were taken from all heifers in the morning before feeding without temporary venous occlusion through jugular vein puncture.

In the sample with temporary venous occlusion, which allowed to estimate vascular wall antiaggregational capacity, the blood was taken from animals' popliteal vein 3 minutes after fixing the tonometer cuff on the thigh with reaching the pressure $10 \mathrm{~mm} \mathrm{mc}$ higher than the systolic one.

The results of the investigation are processed using Student (td) criterion.

\section{Results}

The heifers under investigation demonstrated the downward trend of the content of primary PLP - AHP products in the blood and of the secondary TBA-active compounds, which by the $15^{\text {th }}$ month of life reached $1,29 \pm 0,11 Д_{233} / 1 \mathrm{ml}$ and 3,05 $\pm 0,21 \mathrm{mcmole} / \mathrm{l}$, correspondingly, (by the $12^{\text {th }}$ month of life $1,36 \pm 0,16 Д_{233} / 1 \mathrm{ml}$ and 3,20 $\pm 0,13$ mcmole/l, correspondingly).

The elucidated peroxidation intensity dynamics became possible as a result of the developing tendency in animals to intensify the antioxidant protection of their organism during the investigation period - their plasma antioxidant potential increased from $35,0 \pm 0,12 \%$ at the age of 12 months up to $37,5 \pm 0,16 \%$ at the age of 15 months.

The investigated healthy heifers on rearing demonstrated high integrity of the endothelium lining, which was estimated from the fact of keeping low endotheliocytemia level since 12 months $(1,7 \pm 0,06$ cells $/ \mathrm{ml})$ up to 15 months of age $(1,4 \pm 0,04$ cells $/ \mathrm{mcl})$ (see the table).

Table 1. Vascular indices in black-and-white breed heifers on rearing

( $\mathrm{n}=42, M \pm m$, spring-summer period)

\begin{tabular}{|c|c|c|c|c|c|}
\hline \multirow[t]{2}{*}{ Value parameter } & \multicolumn{4}{|c|}{ Age, months } & \multirow{2}{*}{$\begin{array}{l}\text { Average } \\
\text { values }\end{array}$} \\
\hline & about 12 & about 13 & about 14 & about 15 & \\
\hline $\begin{array}{l}\text { endotheliocytemia, } \\
\text { cells/mcl }\end{array}$ & $1,7 \pm 0,06$ & $1,6 \pm 0,03$ & $1,5 \pm 0,05$ & $1,4 \pm 0,04$ & $1,5 \pm 0,04$ \\
\hline VWAAI with ADF & $1,84 \pm 0,11$ & $1,85 \pm 0,13$ & $1,87 \pm 0,09$ & $1,89 \pm 0,08$ & $1,86 \pm 0,10$ \\
\hline $\begin{array}{l}\text { VWAAI with } \\
\text { collagen }\end{array}$ & $1,73 \pm 0,07$ & $1,74 \pm 0,06$ & $1,76 \pm 0,10$ & $1,78 \pm 0,13$ & $1,76 \pm 0,09$ \\
\hline $\begin{array}{l}\text { VWAAI } \\
\text { thrombin }\end{array}$ & $1,62 \pm 0,03$ & $1,62 \pm 0,02$ & $1,63 \pm 0,06$ & $1,64 \pm 0,07$ & $1,63 \pm 0,04$ \\
\hline
\end{tabular}




\section{MlMacrothink}

Journal of Agricultural Studies

ISSN 2166-0379

2016, Vol. 4, No. 1

\begin{tabular}{|l|c|c|c|c|c|}
\hline $\begin{array}{l}\text { VWAAI with } \\
\text { ristomycin }\end{array}$ & $1,62 \pm 0,06$ & $1,63 \pm 0,10$ & $1,65 \pm 0,10$ & $1,66 \pm 0,13$ & $1,64 \pm 0,10$ \\
\hline $\begin{array}{l}\text { VWAAI with } \\
\text { adrenalin }\end{array}$ & $1,75 \pm 0,10$ & $1,76 \pm 0,11$ & $1,77 \pm 0,08$ & $1,78 \pm 0,04$ & $1,76 \pm 0,08$ \\
\hline $\begin{array}{l}\text { VWAAI with ADF } \\
\text { +adrenalin }\end{array}$ & $1,56 \pm 0,03$ & $1,57 \pm 0,06$ & $1,58 \pm 0,05$ & $1,59 \pm 0,09$ & $1,40 \pm 0,01$ \\
\hline $\begin{array}{l}\text { VWAAI with ADF } \\
+ \text { collagen }\end{array}$ & $1,47 \pm 0,10$ & $1,48 \pm 0,07$ & $1,49 \pm 0,11$ & $1,49 \pm 0,05$ & $1,48 \pm 0,08$ \\
\hline $\begin{array}{l}\text { VWAAI with } \\
\text { adrenalin } \\
+ \text { collagen }\end{array}$ & $1,59 \pm 0,08$ & $1,60 \pm 0,07$ & $1,60 \pm 0,06$ & $1,61 \pm 0,12$ & $1,60 \pm 0,08$ \\
\hline $\begin{array}{l}\text { VWAAI with ADF } \\
\text { +thrombin }\end{array}$ & $1,47 \pm 0,04$ & $1,48 \pm 0,08$ & $1,49 \pm 0,05$ & $1,50 \pm 0,07$ & $1,48 \pm 0,06$ \\
\hline $\begin{array}{l}\text { VWAAI with ADF } \\
\text { +collagen } \\
\text { adrenalin }\end{array}$ & $1,41 \pm 0,06$ & $1,42 \pm 0,11$ & $1,43 \pm 0,09$ & $1,44 \pm 0,08$ & $1,42 \pm 0,08$ \\
\hline $\begin{array}{l}\text { VWAAI with ADF } \\
\text { +thrombin } \\
\text { adrenalin }\end{array}$ & $1,40 \pm 0,10$ & $1,41 \pm 0,06$ & $1,43 \pm 0,05$ & $1,43 \pm 0,07$ & $1,42 \pm 0,07$ \\
\hline $\begin{array}{l}\text { VWAAI with ADF } \\
\text { +collagen } \\
\text { thrombin+ adrenalin }\end{array}$ & $1,36 \pm 0,06$ & $1,37 \pm 0,05$ & $1,38 \pm 0,06$ & $1,39 \pm 0,04$ & $1,37 \pm 0,05$ \\
\hline $\begin{array}{l}\text { VWAAI } \\
\text { VWFAI }\end{array}$ & $1,42 \pm 0,10$ & $1,43 \pm 0,07$ & $1,44 \pm 0,08$ & $1,46 \pm 0,12$ & $1,44 \pm 0,09$ \\
\hline
\end{tabular}

Note: valid dynamics of values is not obtained

In heifers on rearing the TA development time under collagen was $23,7 \pm 0,18$ sec., in the future having the tendency to decrease, reaching $23,0 \pm 0,20 \mathrm{sec}$. by the 15 th month of life.

Similar TA dynamics in animals was found under ADF $(32,7 \pm 0,12 \mathrm{sec}$. and $32,0 \pm 0,19 \mathrm{sec}$. and under ristomycin $(40,5 \pm 0,14 \mathrm{sec}$. and 39,7 $\pm 0,18 \mathrm{sec}$., correspondingly), later thrombin $(45,6 \pm 0,22 \mathrm{sec}$. and 44,8 $\pm 0,13 \mathrm{sec}$., correspondingly) and adrenalin TA $(87,8 \pm 0,26 \mathrm{sec}$. and $86,8 \pm 0,25 \mathrm{sec}$., correspondingly) developed also having the tendency to acceleration during the rearing period.

The downward trend of the TA development time in the investigated animals with the isolated usage of inductors correlated with the decrease of the TA development time with the application of their tested combinations, at the age of 12 and 15 months of life, which were:

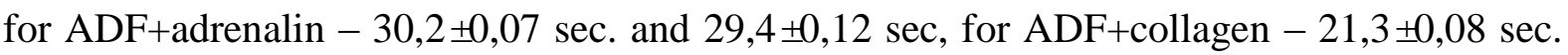

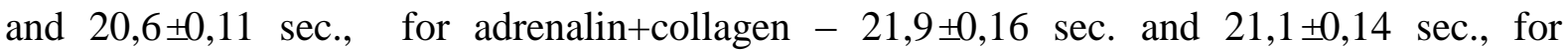

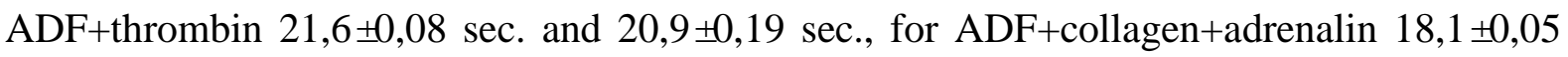

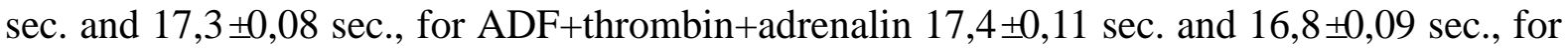

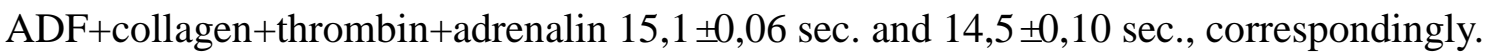

In investigated heifers at the age of about 12 months the TA development time on the background of temporary venous occlusion was $41,0 \pm 0,17 \mathrm{sec}$, remaining practically

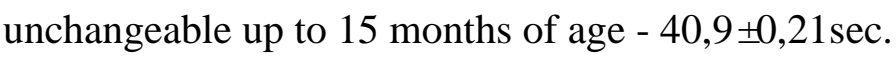

The tendency for TA deceleration in the sample with temporary venous occlusion in the heifers between 12 and 15 months of life was stated under the influence of $\operatorname{ADF}(60,2 \pm 0,19$ sec. and 60,5 $\pm 0,25 \mathrm{sec}$., correspondingly) and ristomycin $(65,6 \pm 0,25 \mathrm{sec}$. and 65,9 $\pm 0,28 \mathrm{sec}$, correspondingly), in the later period there developed thrombin $(73,9 \pm 0,27 \mathrm{sec}$. and $73,5 \pm 0,23$

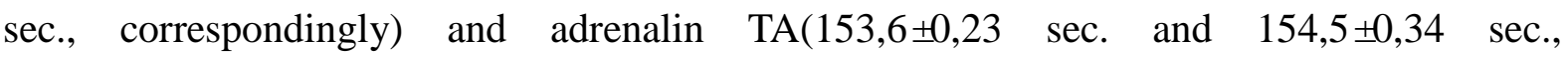
correspondingly). 


\section{Mll Macrothink}

Journal of Agricultural Studies

ISSN 2166-0379

2016, Vol. 4, No. 1

The downward trend of the TA development time on the background of temporary venous occlusion in the investigated animals with the isolated usage of inductors was accompanied with a slight tendency for the acceleration of the TA development time in them with the application of all tested combinations, at the age of 12 and 15 months of life, which were:

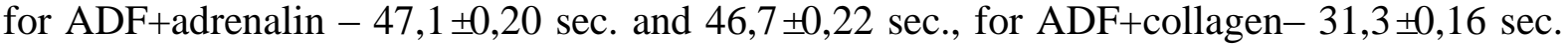

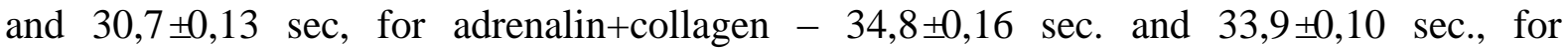

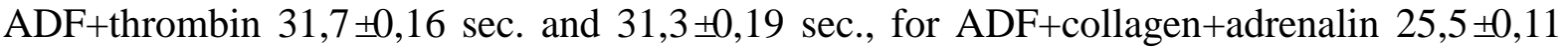

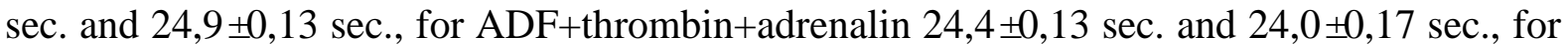

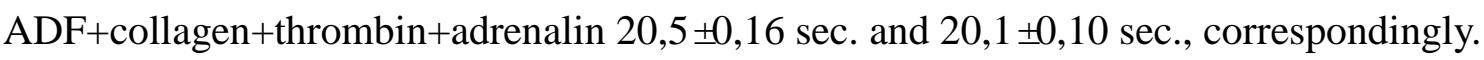

In healthy investigated animals the upward trend for the VWAAI was recorded with all used inductors and their combinations during all the period of observation (see the table). The highest VWAAI was typical for ADF, as this inductor was characterized by maximum TA impediment at venous occlusion. A somewhat lower VWAAI level was recorded with adrenalin and collagen. VWAAI with thrombin (average 1,63 $\pm 0,04$ ) and ristomycin (average $1,64 \pm 0,10)$, also having the tendency for increase during all the period of observation, yielded to them.

The values of vascular wall aggregational activity indices, obtained by application of all tested combinations of inductors, though lower in absolute values, also demonstrated the similar upward trend during all the period of observation.

During the study of the vascular wall anticoagulant activity in the blood of the heifers on rearing the AT III level was estimated using the sample before temporary venous occlusion and after it.

It was stated, that in the blood of healthy heifers between 12 and 15 months of life a slight AT III increase from $128,6 \pm 0,08 \%$ up to $130,6 \pm 0,09 \%$ is evident. Besides, on the background of temporary venous occlusion heifers demonstrate AT III activity increase in the blood from $182,6 \pm 0,16 \%$ up to $190,7 \pm 0,20 \%$, accompanied with the upward trend for the VWACAI.

While studying the vascular wall fibrinolytic activity state in healthy heifers on rearing the estimation of the plasminogen vascular activators intensity was conducted, this was recorded in the euglobulin lysis test before and after the sample with dosaged venous occlusion. In investigated animals a slight tendency for the reduction of the time of spontaneous euglobulin lysis summing up to $4.3 \%$ was observed.

It was found out, that in investigated heifers on rearing the secretion of plasminogen tissue activators, stimulated with the help of temporary venous wall ischemia creation, had the general tendency for intensification - the time of euglobulin lysis after temporary venous occlusion at 12 months was $223,4 \pm 0,29$ min., at 15 months $-214,5 \pm 0,22$ min., providing some VWFAI rise.

Thus, in healthy heifers on rearing on the background of some intensification of plasma antioxidant protection and weakening of PLP in it, a slight rise of the vascular wall antiaggregational, anticoagulant and fibrinolytic activity is stated, providing largely the transition of hemostasis to the level, necessary for the conception and bearing of the posterity. 


\section{Discussion}

Being an anabolic stage in an organism development, the period of rearing of heifers is rather significant for the completion of their development with most full preparation for the pregnancy and realization of their productive qualities (Medvedev and Zavalishina, 2014b).

Vascular system (Medvedev and Zavalishina, 2012; 2014) is very important for bringing the future cow organism together. It is polyfunctional and, through some mechanisms is closely connected with all systems and organs, influencing in their turn the aggregational state of blood (Medvedev, Savchenko and Kiperman, 2015).

Vascular wall activity, in younger productive animals also, determines the level of the factors supporting optimal rheology of blood elements and, by that, the homeostasis of the growing organism.

Low PLP level in heifers on rearing determines weak alteration of endothelium cells, contributing to the optimal antiaggregational capacity of the vascular wall, having the tendency to strengthen apparently due to the intensification of prostacyclin and NO synthesis in it.

During the test with temporary venous wall ischemia in healthy heifers on rearing some increase in the vessel control over adhesive ability of blood platelets, maintained through the influence of desaggregants according to two mechanisms, was observed.

The first one - through the decrease of the density of Ia - IIa and VI collagen receptors-glykoproteides on the thrombocyte membrane under their influence, which was stated in the research indirectly from the tendency for intensification of inhibition in TA with collagen in the sample with temporary venous ischemia.

The second mechanism of control over thrombocyte adhesive capacity in heifers on rearing is connected with the decrease of the Villebrand factor production by the structures of the vessels under the influence of antiaggregants with the decrease on this background of the number of receptors to it (GPI) on the surface of blood platelets (Medvedev, Lapshina and Zavalishina, 2010; Zavalishina, 2013).

In the conditions of intensification of discharge of physiological antiaggregants from blood vessels of heifers on rearing the restriction of the fixation of strong aggregation agonists collagen and thrombin - to the receptors on the thrombocyte membrane is achieved, restraining by that the phospholipase $\mathrm{C}$ activity, inhibiting the phosphoinositide way of thrombocyte activation, weakening the phosphorylation of the contractive system proteins. Under the influence of $\mathrm{PGI}_{2}$ and $\mathrm{NO}$ formed in the vessels the interaction of weak aggregation inductors - ADF and adrenalin - with thrombocyte receptors is also considerably restricted, including low expression of fibrinogen receptors (GPIIв-IIIa) and not high phospholipase $A_{2}$ activity, regulating the discharge of arachidonic acid from phospholipids (Medvedev and Zavalishina, 2011).

It may be supposed, that the elucidated tendency for the TA deceleration with combinations of aggregation inductors on the background of the temporary venous occlusion, observed in the conditions of the real bloodstream, is connected with feebly marked vessel 
antiaggregational influences in relation to TA with combinations of inductors, rather than with their individual application, which to a great extent creates conditions close to in vivo.

The upward trend of the vascular wall antiaggregational activity index values in relation to combined application of aggregation inductors demonstrated functional sufficiency of the vessel disaggregated substance production to retard the typical for animals TA intensification in the conditions close to the real ones.

A significant role in the formation of adequate athrombogenic activity of the vascular wall in heifers on rearing belongs to its high anticoagulant and fibrinolytic properties, which demonstrated a tendency for growth during the investigation period. It is connected to a great extent with unexpressed influence of their low PLP on the vessels, which preserves an optimum functional state of endotheliocytes, including the sufficiency of the synthesis of the substances controlling hemocoagulation in them.

Vessel anticoagulant capacities in the investigated heifers are determined by the elucidated upward trend of the initially rather high production in their subendothelium of one of the strongest physiological anticoagulants - AT III. In these animals the expressed vascular wall control over blood fibrinolytic activity is ensured by the physiologically indispensable intensity of the synthesis of plasminogen activators in it, also having a tendency for intensification.

\section{Conclusion}

Thus, not high PLP activity of the liquid part of blood, recorded in heifers on rearing, largely determines their physiologically significant upward trend of antiaggregational, anticoagulant and fibrinolytic capacity of the vascular walls, providing an optimum level of vascular wall control over the general hemostatic process.

\section{References}

Amelina, I. V., \& Medvedev, I. N. (2008). Evaluation of the dependence of mutagenesis intensity on activity of nucleolus organizer regions of chromosomes in aboriginal population of Kursk region. Bulletin of Experimental Biology and Medicine, 145(1), 68-71.

Amelina, I. V., \& Medvedev, I. N. (2009). Transcriptional activity of chromosome nucleolar organizing regions in population of Kursk region. Bulletin of Experimental Biology and Medicine, 147, 730-732.

Baluda, V. P., Sokolov, E. I., \& Baluda, M. V. (1987). Cuff sample in the diagnostics of the functional state of the vascular part of the hemostasis system. Gematologia $i$ transfusiologia, 9, 51-53.

Barkagan, Z. S., \& Momot, A. P. (1999). Basics of diagnosctics of the hemostasis disorders. Moscow: Newdiamed-AO, 217.

Gavrilov, V. B., \& Mishkorudnaja, M. I. (1983). Spectrophotometric definition of lipid hydroperoxides' content in blood plasma. Laboratornoye delo, 3, 33-36.

Krasnova, E.G., \& Medvedev, I.N. (2013a). Hemostatically significant vessel activity in pigs on vegetable fodder. Selskochozajstvennaya biologia, series "Biologia zhivotnich", 2, 88-92.

Krasnova, E. G., \& Medvedev, I. N. (2013b). Vascular control of hemostasis in milk-and-plant- fed pigs. Aktualniye voprosi veterinarnoj biologii, 2(18), 8-12. 
Medvedev, I. N., Gromnatskij, N. I., Volobuev, I. V., Osipova, V. M., \& Storozhenko, M. V. (2006). Correction of thrombocyte-vascular hemostasis in metabolic syndrome. Klinicheskaja meditsina, 84(1), 46-49.

Medvedev, I. N. (2007). Correction of primary hemostasis in patients suffering from arterial hypertension with metabolic syndrome. Klinicheskaja meditsina, 85(3), 29-33.

Medvedev, I. N., Zavalishina, S. Y., \& Krasnova, E. G. (2010). Mechanisms of hemostasis functioning in biological objects. Mezhdunarodnij vestnik, 1, 52-55.

Medvedev, I. N., Lapshina, E. V., \& Zavalishina, S.Y. (2010). Experimental methods for clinical practice: Activity of platelet hemostasis in children with spinal deformities. Bulletin of Experimental Biology and Medicine, 149(5), 645-646.

Medvedev, I. N., \& Zavalishina, S.Y. (2011). Activity of platelet hemostasis in newborn calves. Russian Agricultural Sciences, 37(5), 404-406.

Medvedev, I. N., \& Zavalishina, S.Y. (2012). The Hemostatic system activity in milk- andplant-fed calves. Dokladi Rossijskoj Akademii Sel'skokhozyajstvennikh Nauk, 6, 62-65.

Medvedev, I. N., \& Zavalishina, S.Y. (2013). Hemostatic system activity in milk- and plant-fed calves. Russian Agricultural Sciences, 39(1), 74-77.

Medvedev, I. N., \& Zavalishina, S.Y. (2014a). Age dynamics of hemostatic vessel activity in calves during the early ontogenesis. Veterinariya, 2, 46-49.

Medvedev, I. N., \& Zavalishina, S.Y. (2014b). Navi attivita emostatico vitelli latte central elettrica. Italian Science Review, 3(12), 174-177.

Medvedev, I.N., Zavalishina, S.Y., Kutafina, N. V., \& Krasnova, E. G. (2015). Approcci metodologici per valutare l'aggregazione piastrinica. Italian Science Review, 1(22), 15-17.

Medvedev, I. N., \& Zavalishina, S.Y. (2015). Characteristics of the hemostatic system in cows during pregnancy. Russian Agricultural Sciences, 41(1), 48-52.

Medvedev, I. N., Savchenko, A. P., \& Kiperman, Y. V. (2015). Dynamics of the Intravascular Activity of Platelets in Young Men with High Normal Blood Pressure Regularly Practicing Physical Activity. Biology and Medicine (Aligarh), 7:1 BM-069-15.

Shitikova, A. S. (1999). Visual micromethod of thrombocyte aggregation reseach. In the book Gemostaz. Fiziologicheskiye mechanizmi, prontsipi diagnostiki osnovnich form gemorragicheskich zabolevanij. St.Petersburg, 49-52.

Simonenko, V. B., Medvedev, I. N., Mezentseva, N. I., \& Tolmachev, V. V. (2007). The antiaggregational activity of the vascular wall in patients suffering from arterial hypertension with metabolic syndrome. Klinicheskaja meditsina, 85(7), 28-30.

Simonenko, V. B., Medvedev, I. N., \& Kumova, T. A. (2010). Pathogenetic aspects of hypertension in case of metabolic syndrome. Voenno-meditsinskij zhurnal, 331(9), 41-44.

Volchegorskij, I. A., Dolgushin, I. I., Kolesnikov, O. L., \& Cejlikman, V. J. (2000). Experimental modeling and laboratory estimation of organism adaptive reactions, 167.

Zajnulina, M. S. (1999). Definition of endotheliocytes in the blood. In the book Gemostaz. Edited by Petrischev N. N., Papayan L. P. St.Petersburg, 72-73.

Zavalishina, S.Y. (2012a). Hemostatic activity of vascular wall of newborn calves. Russian Agricultural Sciences, 38(1), 51-54. 


\section{Macrothink}

Journal of Agricultural Studies

ISSN 2166-0379 2016, Vol. 4, No. 1

Zavalishina, S. Y. (2012b). Activity of vascular hemostasis in milk-fed calves. Russian Agricultural Sciences, 38(4), 321-323.

Zavalishina, S. Y, Medvedev, I.N. (2012). Antiaggregational abilities of vascular walls in milk- and plant-fed calves. Problemi biologii produktivnikh zhivotnikh, 1, 31-36.

Zavalishina, S. Y. (2013). State of the hemostatic system in iron-deficient newborn calves. Russian Agricultural Sciences, 39(4), 350-353.

\section{Copyright Disclaimer}

Copyright for this article is retained by the author(s), with first publication rights granted to the journal.

This is an open-access article distributed under the terms and conditions of the Creative Commons Attribution license (http://creativecommons.org/licenses/by/3.0/). 